\title{
Effectiveness of Low Cost Materials on Diverse Achievers in the Teaching of Physics at Secondary Level
}

\author{
*Saifullah Khan: PhD (Education) Scholar, Northern University Nowshera, Pakistan \\ **Rehmat Ali Farooq: Professor, Dean Faculty of Arts and Social Science, NUN \\ ***Nilsa Fleury: Professor, York College, USA
}

\begin{abstract}
The equipment's of science teaching in the most of secondary school is not available in Pakistan. The main purpose of this research is to find the effectiveness of low cost materials on diverse achievers in the physics instructing at secondary level. The nature of the study was experimental. The most suitable design for this experiment was Pre-test, post-test equivalent group design. A sample of 40 pupils was carefully chosen from Government High School No. 2 Nowshera Cantt. The experiment continued for six weeks. Independent sample t-test was used for the analysis of data. The group which has been instructed with low cost teaching aids showed successful result scores in the posttest and their achievement level further gets improved. It has been suggested that teachers training institutions ought to build up such a training programs, which would enhance the capacities of teachers in the selection and in the development of apparatuses, using low cost materials for practical work
\end{abstract}

Keywords: Low Cost Materials, Science, Low Achievers and Physics

\section{Introduction}

$21^{\text {st }}$ century is the century of science. Those countries are considered developed who have quality education system especially in science. Unfortunately, science education of Pakistan cannot be compared with the developed countries. Here the resources of teaching science are not sufficient. That's why the researcher is finding an alternative for the teaching of science considering the economic conditions of the country. Therefore, the researcher tried to find the effectiveness of low-cost materials in the teaching of physics as cost-effective materials that are readily available and useful in countries such as Pakistan where resources are missing, especially in secondary education. Therefore, science teachers may take their lessons with

\footnotetext{
"PhD (Education) Scholar, Northern University Nowshera, Pakistan. Email:saifnsr66@gmail.com

*** Professor, Dean Faculty of Arts and Social Science, Northern University Nowshera.

Email: drfarooqch43@gmail.com

**** Doctor of Education (Ed), Professor, York College, USA. Email: nilsa.fluery@ yahoo.com
} 
cheaper materials available to their surroundings. The same low-cost materials have proved useful in developing and backward countries such as Pakistan, Sri Lanka, Nigeria, Bangladesh and India in science education. Yitbarek (2012) says that if teachers want their learners to be acquainted with what inventors do but actually how inventors do then the learners need to be able to perceive measure, match, categorize, define and assess. All human being is born with the capabilities to investigate but how will they do it is to be learnt. Therefore, teaching of science should be based on nearby accessible materials and it will make teaching and learning process more practical even when the settings for teaching are not favorable. It is supposed that with the help of nearby obtainable materials maximum of the elementary school practical lessons can be executed in a very little period with no or little monetary contribution and devoid of lengthy time of preparation.

\section{What is science?}

Science is originated from a Latin word "scientia", that means "knowledge" or "understanding." Formerly, this term does not apply to today's practical knowledge and experience. It is closer to the philosophy of empirical research. The word "wisdom" is close to science, according to Hobbs, who predicted his future in his experiences. The word "scientist" was introduced in the 1900 era. Recently science has lost its original meaning and can explain as "Science is a set of objective and mathematical methods" (Ross, 1990). In short, scientific research is limited to research that has natural causes. Finally, scientific evidence must be empirically justified (Loo, 2001).

\section{Nature of Science}

Scientific education refers to the content of natural sciences and higher education. Scientific education is therefore also linked to the social aspects of society. Hodson (1998) presented some aspects of academic education. Some believe that it will be the choice and education of future scientists; others believe that they meet the needs of the economy, the social crisis and environmental issues. A good scientific education program contributes to the socio-economic growth of a state. This offers pupils a scientific information that helps to find the most socioeconomic and environmental problems (Mohanty, 2004).

Jacques and Poisson (2001) explain that the scope of university instruction varies from one country to other such as focus on scientific content, teaching methods, apparatuses and scientific standards. Scientific learning concentrates in six diverse areas. This includes areas of knowledge, operational skills, scientific processes, application, creative areas and 
preferences. Scientific knowledge should strive for critical thinking of the pupils. Acute thinking must be circumstantial. The presentation of this notion in scientific learning is associated with jobs, difficulties and complications of the curriculum (Bailin, 2002).

\section{Aims of Science Education}

Ediger (1999) set 3 goals for the teaching of science. The $1^{\text {st }}$ goal is concerned with the mental field that includes information of thoughts, notions and generalities. The $2^{\text {nd }}$ is a method that analyzes the problem that students are listening to. The second goal is very small. This means that students in schools or higher education do not learn to solve problems around the world. That is why it intends to produce science and society.

Osborne (2000) argues that the goal of university education is clear: to create excellence in creating a place. Students should understand the most important logical perceptions and their influence to the realm of modern technology. In the meantime, pupils must comprehend the history of science to understand society's improvement. Bybee and DeBoer (1994) gather three academic educational goals. According to scientific results, students will learn the scientific process and acquire scientific knowledge.

\section{Secondary Education}

Secondary education in Pakistan is a stage which mostly consists of class 9 and 10. There are two purposes of secondary education mentioned in the national educational policy 1970.In the first stage it is the final stage for some students because here many students leave education for many reasons in their lives. Having this aim in the thoughts, the secondary education should have a decent ground of science, technical and vocational information. The learners who have not capacity to progress with their education should have fair chances of looking for their professions. The $2^{\text {nd }}$. aim of secondary education is to help as an introductory phase for those learners who want to persist with their education at a higher stage. Therefore, secondary education should offer a respectable ground at college and university for seeking higher education. Mohanty (2004) also state that at this phase and time the learners may be successful listened towards a profession as upcoming scientists.

\section{Instructional Strategy and Method}

Colletter and Chiapiappett (1989) state that "A teaching strategy is a general curriculum that includes a lesson-based structure, learning behaviors, and a general description of the tactics developed to implement the strategy." A learning strategy is "management of education or 
general planning to attain specific objectives". The method of teaching is class demonstration in a classroom (Sharma, 2004).

\section{Difference between Instructional Strategy and Method}

The method of teaching is founded on conventional organizational theory, and didactic strategies are based on modern organizational concept. The key basics of the instructional technique are content and demonstration, while the basic elements of educational strategies are the conditions of behavior and learning. Teaching methods emphasize knowledge of the subject, and didactic strategies put emphasis on achieving educational goals. Teachers, however, teach subjects as a general educational strategy and achieve desired goals, while teaching methods are a special way to teach lessons in order to achieve the desired goal. In conclusion, this method is part of the teaching strategy, namely general (Sharma, 2004).

\section{Low Cost Teaching Aids}

Savikumar (2014) notes that low-cost teaching aids are made with simple materials that cost very little to involve teachers and students. In expensive tools, learning with little or no money could make learning effective, comprehensive and fascinating. The science teacher, with some skills and enthusiasm, can replace many devices with an adequate, if unconventional, improvised replacement. Low-cost teaching aids have the advantage of providing learning methods for the learning process. When teachers and students plan, create, or create their own teaching materials, they inevitably show pride and joy in maximizing their use. Effective science education depends on three factors: teacher, equipment and material. Close by formed low-cost appliances, instructional aides could be better help the requirements of the tutor, the scholar and the course are at ease to uphold.

\section{Development of Low Cost Teaching Aids}

The foremost job of the instructor is the development of cost-effective teaching materials using locally available materials. The teacher should be an active participant in the preparation of the cost-effective teaching materials. The teacher himself or with the help of students can carry out the process. In order to design the effective learning aid at a low cost, the teacher should have a thorough knowledge of the goals and scientific concepts. Teachers should have adequate knowledge to provide learning experiences, locally available resources and environmental conditions. In order to improve the learning process, science teachers who are genuinely interested in this area are preparing their own teaching materials using available resources. With sufficient support from supervisors, parents, and the community, the quality and effectiveness of these low-cost educational tools can be improved. 


\section{Effective Design of Low Cost Teaching Aids}

The following basic principles can be used in the creation of inexpensive teaching aids:

a) The concept should be explained accurately and easily so that all students can understand the situation.

b) It needs to attract attention and promote sharp thinking.

c) The cost-effective teaching materials must be very simple and easy to handle.

d) It can save a lot of money and avoid some complex applications.

\section{Advantages of Low Cost Teaching Aids}

Improvisation and experiments play a key part in the success of scientific instruction. It helps to have more knowledge and understanding. Improvisation makes science action instead of talking. It promotes maximum participation of students in the learning process. Improvisation ensures a longer retention of the information gained. It offers first-hand experience in a variety of ways.

a) Develops scientific attitude in children.

b) Maintains research spirit in children.

c) Promotes interaction between teachers and students.

d) Promotes interaction between students.

e) Improvisation generally involves an interest and involvement in the classroom.

f) Promote cooperative attitude in children.

g) Develops the self-confidence of the students.

h) Helps students use their free time helps the school to take care of themselves.

i) With the help of the improvised aids, the presentation of the contents will be attractive and stimulating.

j) It also facilitates the dissemination of new curriculum ideas. It helps to improve the efficiency.

k) It speeds up the learning speed and increases the retention margin.

1) Mind-related learning experiences are far more effective than abstract learning experiences.

Although, India is an economically backward country, teachers should look positively at affordable educational materials. Science teachers should encourage them to provide lowcost teaching materials using locally available resources. Students should get a very clear picture of the resources available in the village. You can even try to allocate it to help production. Teachers should, where possible, use teaching this kind of strategy and teaching 
aids (Savikumar, 2014). Science teachers can revive their lessons with inexpensive materials. The same cheap materials were found for use in Sri Lanka, Nigeria, Bangladesh, India, etc. Cheap materials refer to the systematic way of constructing the device (Yitbarek, 2012).

To improve the situation, many national, regional and international projects have been launched. However, in many cases their results were far below expectations. The World Bank financed secondary education in over 100 projects; usually the device's mechanisms were an integral part of the total cost of ownership. In the banks' assessments, almost half of the results were rated as negative. An internal banking audit (Hage et al., 1988) stated that the equipment was considered an insurance company. Teacher training components have been included in $14 \%$ of equipment component designs. Banking procurement tenders ordering. In some cases, the equipment was included in twenty-two-year sets still in original packaging (Schmidt, 1983).

Research and improvement attitudes and SPS (Turpin, 2000, Uzal et al., 2010) learned to benefit teachers. After the notification, the scientist decided to read and readily useable stuffs and by comparing the opinions of science teachers. In the end, they did not find an opinion on scientific experiments with readily available materials. Accordingly to the results of another study (Önen \& Çömek, 2011), the trainee teachers positively assessed the lessons using readily available materials. In a same research, Holstermann et al. (2010) pupils who had experience working with non-experienced students. In the end, they found that they might manipulate pupil's interests in a different way. They too pointed the right practice. In contrast to practical research, Sinan and Usak (2011) carried research in a well-resourced biochemical laboratory. The project also offers training for communities; Volunteers receive 31 hours of training and science teachers 27 hours. More than 10,000 children and 1,000 teachers participated in these informal learning activities last year. In many countries the lack of education in science is the lack of adequate tools including equipment's. Modern learning curricula and discovery-based textbooks are nowadays in practiced but lacking practical work. This is doubtful whether pupils have able to understand science, if books and study programs were based on the teaching of teachers and teachers. Several domestic, provincial and global ventures have been started to improve the situation. However, in many cases, their performance was much lower than expectations. The World Bank has financed secondary education in more than 100 projects. In general, the mechanism of the instrument is an integral part of the total cost of ownership. Almost half of the results were classified as negative for bank ratings. They noted that the material was reinforced at the cost of extra 
elements such as training of instructors. The data of teacher training was only taken into account in $14 \%$ of the components of the equipment. Other successful projects in the supply and distribution of equipment did not significantly increase the worth of scientific instruction. In few instances, apparatus was not used and 20-year packaging units were found in their original packaging (Schmidt, 1983).

\section{Statement of the Problem}

This study investigated the "Effectiveness of Low Cost Materials in the Teaching of Physics at Secondary Level "was a new study because very limited studies had been conducted in this regard. Therefore, the researcher tried to find out the outcomes of this method to give a diversity of methods for science teachers because the prevailing methods are not fulfilling the needs of the science students.

\section{Objectives of the Study}

The study was based on the following objectives:

a) To explore the effect of low cost materials on the achievement of students in the subject of physics at secondary level

b) To study the effect of low cost materials on the performance of low achievers and high achievers of experimental and control groups in the subject of physics at secondary level.

\section{Significance of the Study}

The study will explore new ideas for using the low cost materials in the teaching learning process. It will also furnish support both to science students and teachers for developing low cost and local available materials. This study will helpful for the practical involvement of the students especially where lack of laboratory equipment's. It will also give a new idea for curriculum developer to include such items in science subjects.

\section{Delimitation of the Study}

The study was delimited to:

a) The class $\mathrm{X}$ male pupils of science studying physics in public sector schools in Khyber Pakhtunkhwa.

b) During the treatment, the following four units of physics of Grade $\mathrm{X}$ text book were covered: Simple Harmonic Motion and Waves, Sound, Geometrical optics, and Electrostatics. 


\section{Method and Procedure}

\section{Research design}

The pretest post-test control and alike experimental group design was used for this study.

\section{Population}

The total 131,518 pupils of class $\mathrm{X}$ in Khyber Pakhtunkhwa was the population for this study (EMIS, 2013).

\section{Sample}

Sample of this study was comprised of 40 students of grade X of Govt. High School No.2 Nowshera Cantonment. Each group was composed of 20 students each in control and experimental groups. The sample students were selected through pair random sampling technique by pre-test scores.

\section{Research instruments}

An objective type teacher made pre-test / post-test was used for the collection of data. Each test was based on hundred items in the subject of physics of grade $\mathrm{X}$. The consents of the subject experts were weighed in the construction of tests. Furthermore, the services of language expert for proof reading of this report were also hired. The pre-test and post-test were the same in difficulty level. These test items i.e. MCQS were based on the selected units of grade X physics which were; Simple Harmonic Motion and Waves, Sound, Geometrical optics, and Electrostatics. Experimental group were taught through low cost material while control group were taught through traditional material. Same post- test was administered after seven weeks of the completion of experiment while retention-test was administered after a period of two months.

\section{Procedure}

The following procedure was adopted during the experiment:

\section{Selection of Teachers}

Two teachers from Government High School No2, Nowshera Cantt having the same requirement, with teaching experience and substantially equal teaching potentialities were chose for the teaching of physics of class- $\mathrm{X}$ to the control and experimental groups. The teacher offering for teaching experimental group was previously trained by the science project DCTE KP in the construction and use of low cost materials in the teaching learning strategies.

\section{Treatment}

Two different strategies were employed for the two groups. Experimental group was taught 
with the help of low cost-materials and the control group was taught through conventional way of teaching. Both groups were taught, the four selected units from the physics text book of Grade X: a) Simple Harmonic motion and Waves b) Sound (iii) Geometrical Optics and, c)) Electrostatics. The experiment was started on $15^{\text {th }}$ April 2013 and completed on $30^{\text {th }}$ May 2013.

\section{Day Wise Detail of Activities}

Day 1-: The researcher visited the selected school on first day and met the principal and the teachers which were selected before the commencement of the experiment. The honorable principal of Government High School No.2 Nowshera Cantt warmly welcomed the researcher and directed his school teachers to fully cooperate in treatment of the study. The researcher thanked the principal and the two teachers for their cooperation in the study process. After that the researcher along with the principal and the teachers met the sample students in a very friendly environment. After introduction and familiarity with the sample students a little refreshment was given to the sample students from the side of research to create a free environment. After that a pre-test was given to 40 sample students in order to know their previous knowledge consisting of 100 multiple choice questions. The time for completion of the test was 3 hours. The researcher helps the students to understand the items of the test. After the completion of the test the researcher collected back the papers from the sample students in order to mark it.

Day 2- The researcher went to the school again on the second day with a prepared list of scores of the students. Two group experimental and control were already formed consisting of equal number of students i.e. 20 each in both groups. Both groups included equal number of high achiever, average and low achiever students. Two separate classrooms were allotted to the experimental and control groups. The researcher welcomed both the groups. Two already qualified trained secondary school science teachers were assigned to teach experimental and control groups. These teachers were introduced to their assigned groups in the presence of the researcher and school principal.

Day 3- Both the groups were taught the same topic "Simple Harmonic Motion" of the unit. The experimental groups were taught with the help of locally available low cost material (Mass attached to a spring and a swing) and were practically engaged in the activities. On the other hand, control group was taught through routine method. 
Day 4- Simple Pendulum was taught through low cost materials; string and a small mass attached to the spring to the experimental group.

Day 5- Experimental group learned waves, its types and properties with the help of water in a container and pieces of paper.

Day 6- The students of experimental group were demonstrated waves properties through Ripple Tank Model which was developed from locally available low cost materials such as: wooden strips, transparent plastic and toy torch.

Day 7- The second unit "geometrical optics" was taught to both groups. Topic reflection of light was explained and demonstrated through mirror strips only to the experimental group.

These activities were carried with the help of low cost materials to the experimental group for 40 days. Each chapter was allocated different days according to the contents and length of the chapter. On the other hand, control group was taught the same topics but without the use of low cost materials. After the treatment was over, post-test was administered to the sample students. The assigned teachers and students were thanked at the end of treatment.

\section{Results}

The core of the study was to analyze the effectiveness of low-cost materials in physics education at secondary level.

Table 1: Pre-Test comparison of underperforming students of experimental and control groups

\begin{tabular}{cccccc}
\hline Low Achievers & N & S.D & Mean & Obtained Value & Table Value \\
\hline Experimental Group & 11 & 2.65 & 25.36 & & \\
Control Group & 11 & 2.65 & 24.63 & 0.64 & 1.725 \\
\hline
\end{tabular}

Table 1, shows that there were 11students in each experimental and control low achiever groups. The standard deviation of experimental low achiever was 2.65 while for low achievers of control group was also 2.5. Similarly the mean of experimental group was 25.36 and the mean of control group was 24.63. On the other hand, the calculated value of $t$ was 0.64 which was less than the table value 1.725 . It shows that both the low achiever groups i.e. experimental and control groups were almost equal in knowledge before the start of the experiment. 
Table 2: Pre-Test comparison of high performing students of experimental and control groups

\begin{tabular}{cccccc}
\hline High Achievers & N & S.D & Mean & Obtained Value & Table Value \\
\hline Experimental Group & 09 & 4.91 & 36.11 & & \\
Control Group & 09 & 4.76 & 35.22 & 0.39 & 1.746 \\
\hline
\end{tabular}

In the table 2, the analysis shows that there were 09 students each in experimental and control high achiever groups. The standard deviation of experimental low achiever was 4.91 while for low achievers of control group was also 4.76. Similarly the mean of experimental group was 36.11 and the mean of control group was 35.22. On the other hand, the calculated value of $t$ was 0.39 which was less than the table value 1.746.It shows that both the low achiever groups i.e. experimental and control groups were almost equal in knowledge before the start of the experiment.

Table 3: Post-Test comparison of underperforming students of experimental and control groups

\begin{tabular}{llllll}
\hline Low Achievers & N & S.D & Mean & Obtained Value & Table Value \\
\hline Experimental Group & 11 & 12.06 & 52.63 & & \\
Control Group & 11 & 2.14 & 36.72 & 4.31 & 1.725 \\
\hline
\end{tabular}

In the table 3, the analysis shows that there were 11 students each in experimental and control low achiever groups. The standard deviation of experimental low achiever was 12.06 while for low achievers of control group was 2.14. Similarly the mean of experimental group was 52.63 and the mean of control group was 36.72. On the other hand, the calculated value of it was 4.31 which were greater than the table value 1.725. It showed that students in the experimental group learned better than the students of control group.

Table 4: Post-test comparison of high performing students of experimental and control groups

\begin{tabular}{llllll}
\hline High Achievers & N & S.D & Mean & T-Value Obtained & Table Value \\
\hline Experimental Group & 09 & 4.02 & 76.77 & & \\
Control Group & 09 & 5.70 & 53 & 10.22 & 1.746 \\
\hline
\end{tabular}


In the table 4, the analysis shows that there were 11 students each in experimental and control low achiever groups. The standard deviation of experimental high achiever students was 4.02 while for control group, it was also 5.70. Similarly the mean of experimental group was 76.77 and the mean of control group was 53. On the other hand, the calculated value of $t$ was 10.22 which was greater than the table value 1.746 on post-test. The table represents that high achievers students of experimental group were actively involved in the learning process as compared to students of the control group.

\section{Discussion}

The use of low cost material is very important in the teaching of science subjects especially, in physics. It has been receiving much attention by educators and students. Sufficient theories and practices are available for the practical application of this method in the science classrooms.

Furthermore, the contrast between mean post-test results of low achiever of the investigational group and control group with respect to achievement in physics was important at (0.05) level. It's suggests that low achievers of the investigational group, who were educated via 'low cost materials' did considerably superior than control group who were educated via traditional method of instruction. As a result, the null hypotheses were disposed. This study confirms that the views of Haq and Khurram (2018) who were of the opinion that low achievers of experimental group outscored control group in language learning. The inherent value in experiments in science is that, they provide breaks in classroom activity and act as motivation for students (Kranz, 2008). However, experiments also help to develop manual skills, illustrate abstract theories and promote problem-solving thinking (Bradley, Durbach, Bell \& Mungarulire, 1998).

In the same way, the variation between the mean post-test scores of high achievement of equally the investigational and control groups in the teaching of physics was also important at (0.05) level. Therefore, the null hypotheses were discarded, in the support of investigational group. A key aspect of this principle is its simplicity and its good overview of the used instruments (Schwan, 2005). This study also confirms the opinion of Obendrauf, (2006; Haq \& Khurram, 2018).

\section{Conclusions}

The below mentioned conclusion were prepared on the base of statistically investigation and results of the study: 
a) Using of low cost materials is found to be more fruitful for teaching science especially physics contrary to conventional/traditional teaching. It provides ample opportunities to students of science to practically engage with the theoretical work.

b) Furthermore, it is also concluded that low achiever students of the experimental group showed brilliant performance over the control group as they were instructed with the help of low cost materials and took keen in interest in the learning process.

c) The use of low cost materials also made an impact in the achievement of high achiever students and thus supersedes the control group because the routine method was not comparable to this. The involvement of students with practical work and demonstration with the help of low cost materials enhanced the learning capabilities of students of the experimental group.

\section{Recommendations}

The following suggestions are recommended:

a) The consequences of the paper in hand prefer utilizing of low cost materials in the teaching of physics. Therefore, it is suggested that when apply this technique of instruction, educator must develop relevant and locally available low cost materials for the purpose of science teaching.

b) The government should implement in schools that if equipment's for science subjects are not enough in any schools then the strategy of low cost material should be adopted as science subjects needs practical work and it makes a student learned by doing.

c) Teachers training institutions should develop such as training programs which would enhance the capacities of teachers in the selection and in the development of apparatuses, using low cost materials for practical work.

\section{References}

Bailin, S. (2002). Critical Thinking and Science Education. Science \& Education, 11, 361375.

Bradley, J. D., Durbach, S., Bell, B., \& Mungarulire, J. (1998). Hands-On Practical Chemistry for All - Why and How Journal of Chemical Education, 75 (11), 1406 1409.

Bybee, R.W. \& DeBoer, G. (1994). Research on the goals for science education. InD.L. Gabel (Ed.), Handbook of research on teaching and learning of science (pp. 357387). New York: Macmillan. 
Colletter, A.T. \& Chiapiappett, E. (1989). Science Instruction in the Middle Secondary School (2nd ed.). Merrill Publishing Company.

Ediger, M. (1999). Problems in Teaching Science. (ERIC Document Reproduction Service No. ED 431 625).

Hage, J., Garnier, M. \& Fuller, B. (1988). The active state, investment in human capital, and economic growth. American Sociological Review, 53, 824-837.

Hodson, D. (1998) Teaching and Learning Science: Towards A Personalized Approach. Buckingham - Philadelphia, Open University Press.

Holstermann, N., Grube, D. and Bögeholz, S. (2010). Hands-on activities and them influence on students' interest. Research in Science Education 40, 743-757.

Jacques, H. \& Poisson, M. (2001). Science Education for Contemporary Society: Problems, Issues and Dilemmas. Beijing, China: Retrieved from ERIC database. (ED452055)

Kranz,J.(2008). Schulentwicklung konkret: Baustein "Schülermotivation". Berlin: Cornelsen Scriptor.

Loo, S. P. (2001). Islam, science and science education: Conflict or concord? Studies in Science Education, 36 (1), 45-77.

Mohanty, R. (2004). Science Education Program in Secondary Schools. New Delhi: Deep and Deep publication.

Obendrauf, V. (2006).Fundamental Microscale Experiments from Austria, Presented Worldwide. In M. Hugerat, P. Schwarz, \& M. Livneh, Microscale Chemistry Experimentation for all Ages (S. 300 - 321). Haifa: The Academic Arab College for Education.

Önen, F. and Çömek, A. (2011). Öğretmen adaylarının gözüyle basit araç-gereçlerle yapılan fen deneyleri. Batı Anadolu Ĕ̆itim Bilimleri Dergisi. 3(1), 45-72.

Osborne, J. (2000). Keynote speech. In M. Poisson (Ed.), Science education for contemporary society: Problems, issues and dilemmas (pp. 8-12). Beijing, China: Retrieved from ERIC database. (ED 452055)

Ross, G.M. (1990). Science and Philosophy in Comparison to the History of Modern Science: Rout ledge.

Savikumar. R. (2014). IMPACT OF LOW COST TEACHING AIDS IN TEACHING SCIENCE. Innovative Thoughts International Research Journal,2 (3), (31-44).

Schmidt, H. G. (1983). Problem-based learning: Rationale and description. Medical Education, 17, 11-16.

Schwan, T. (2005). Elektrochemieim Low-Cost Maßstab: Elektrolyse, Schmelzelektrolyse 
und galvanische Elemente im Kontext der Unterrichtsreihe „Atombau und chemische Bindung “. Der Mathematischeund Naturwissenschaftliche Unterricht, 58 (3), 169 175.

Sharma, R. A. (2004). Technological foundation of Education. Meerut, India: Surya Publication.

Sinan, O. and Uşak, M. (2011). Biyoloji Öğretmen adaylarının bilimsel süreç becerilerinin değerlendirilmesi. Mustafa Kemal Üniversitesi Sosyal Bilimler Enstitüsü Dergisi, 8(15), 333-348.

Turpin, T. J. (2000). A study of the effects of an integrated, activity-based science curriculum on student achievement, science process skills, and science attitudes. Ed.D. dissertation, University of Louisiana at Monroe, United States. Pro Quest Digital Dissertations Database, (Publication No. AAT 9993727), Retrieved October, 15, 2011.

Uzal, G., Erdem, A., Önen, F. and Gürdal, A. (2010). Basit araç gereçlerle yapılan fen deneyleri konusunda öğretmen görüşleri ve gerçekleştirilen hizmetiçi eğitimin değerlendirilmesi. Necatibey Ĕ̆itim Fakültesi Elektronik Fen ve Matematik Eğitimi Dergisi, 4(1), 64-84.

Yitbarek, S. (2012). Low cost apparatus from locally available material for teaching learning science; AJCE, 2012, 2(1) Special issue.

Haq, Z., Khurrum.B.A. (2018 ). Improvement of Writing Skills by Using Activity Based Learning at Grade-VI. Journal of Social Sciences and Humanities, 57(1), 17-27 